http://dx.doi.org/10.1590/1678-4162-7942

Arq. Bras. Med. Vet. Zootec., v.68, n.2, p.397-403, 2016

\title{
Hypoxia increases susceptibility of Pacific white shrimp to white spot syndrome virus (WSSV)
}

[Condição de hipóxia aumenta a susceptibilidade do camarão branco do Pacífico ao vírus da mancha branca (WSSV)]

\author{
M. Lehmann ${ }^{1}$, D.D. Schleder ${ }^{1 *}$, C. Guertler ${ }^{2}$, L.M. Perazzolo ${ }^{2}$, L. Vinatea ${ }^{2}$ \\ ${ }^{1}$ Núcleo de Pesquisa em Pesca e Aquicultura -(NUPA Sul-1) - Instituto Federal Catarinense - Araquari, SC \\ ${ }^{2}$ Universidade Federal de Santa Catarina- (UFSC) - Florianópolis, SC
}

\begin{abstract}
The present study aimed to evaluate the mortality, reactive oxygen species production (ROS) and total hemocyte counts (THC) of the marine shrimp Litopenaeus vannamei infected with the white spot syndrome virus (WSSV) at three levels of oxygen saturation. For this, 360 shrimp (20 $2 \mathrm{~g}$ ) were distributed in 24 tanks (60L), divided in two groups (infected and non-infected), which were subjected to 30,60 and $100 \%$ of dissolved oxygen saturation (in quadruplicate). During 96 hours after infection, daily hemolymph samples were collected for hemato-immunological parameter evaluation (THC and ROS) and dead animals were removed and computed to assess cumulative mortality rates. In the infected group, animals subjected to $100 \%$ saturation showed higher ROS production $(\mathrm{P}<0.05)$ after 48 hours, while THC was significantly reduced $(\mathrm{P}<0.05)$, regardless of oxygen saturation. The hypoxia resulted in high mortality when compared to $100 \%$ saturation condition. In the uninfected group, no significant differences were observed in all evaluated parameters. Thus, the hypoxia condition increased the susceptibility of shrimp to the infection of WSSV, which may be partly related to the low ROS production showed by the animals subjected to $30 \%$ oxygen saturation.
\end{abstract}

Keywords: Litopenaeus vannamei, WSSV, dissolved oxygen saturation, immune response, mortality

\section{RESUMO}

O presente estudo teve por finalidade avaliar a mortalidade e a contagem total de hemócitos (CTH) e espécies reativas de oxigênio (EROs) de camarão Litopenaeus vannamei infectados com o vírus da mancha branca (WSSV) e submetidos a três níveis de saturação de oxigênio. Para tanto, 360 camarões $(20 \pm 2 g)$ foram distribuídos em 24 tanques (60L), divididos em dois grupos, infectados e não infectados e submetidos a 30, 60 e 100\% de saturação de oxigênio (em quadruplicata). Após a infecção, diariamente foram coletadas amostras de hemolinfa dos animais para avaliação dos parâmetros hematoimunológicos (CTH e EROs) e foi estimada a mortalidade, por 96 horas. No grupo com infecção, os animais submetidos à saturação de $100 \%$ apresentaram um aumento na produção de EROs $(P<0,05)$ após 48 horas, ao mesmo tempo em que a CTH demonstrou uma redução $(P<0,05)$ independentemente da saturação do oxigênio, e a condição de hipóxia acarretou maiores mortalidades quando comparada à do grupo com $100 \%$ de saturação. No grupo sem infecção, não foram observadas diferenças significativas nos parâmetros avaliados nem mortalidade. Dessa forma, pode-se concluir que a hipóxia aumentou a susceptibilidade do camarão à infecção com o vírus da mancha branca, que pode estar, em parte, relacionada com a baixa contagem de hemócitos e produção de EROs observadas nos animais submetidos a essa condição.

Palavras-chave: Litopenaeus vannamei, WSSV, saturação de oxigênio, resposta imune, mortalidade

Recebido em 27 de agosto de 2014

Aceito em 26 de novembro de 2015

*Autor para correspondência (corresponding author)

E-mail: delano.schleder@ifc-araquari.edu.br 


\section{INTRODUCTION}

Diseases are the result of an unbalanced interaction between pathogen, environment and host. Thus, an animal in a safe environment may carry an infectious agent without manifesting signs of the disease. In the production of aquatic organisms, the occurrence of inadequate water quality parameters may disturb their homeostasis, leading to increased susceptibility to diseases (Le Moullac and Haffner, 2000).

In shrimp, like other invertebrates, protection against diseases solely depends on the innate immune system. There is no immunological memory in these animals, and the non-self recognition depends on pattern recognition proteins (PRPs) that detect pathogen-associated molecular patterns (PAMPs). In general, the innate immune system of invertebrates is related to their hemolymph, composed of a cellular fraction (hemocytes) and a liquid fraction (plasma), where humoral factors are dissolved (Barracco et al., 2008).

Hemocytes are immunocompetent cells responsible for cellular responses in crustaceans. These cells respond to the invasion of microorganisms and parasites, destroying them by phagocytosis or isolating them in hemocyte aggregates, forming nodules and capsules (Barracco et al., 2008). During phagocytosis, the microorganisms are engulfed by hemocytes, and molecules with potent microbicidal activity and cytotoxicity are produced and released. (Bogdan et al., 2000; Campa-Córdova et al., 2002). Reactive oxygen species (ROS) are molecules with unpaired electrons in their outer layers, which oxidize surrounding components, such as membranes and proteins. Thus, thanks to their microbicidal potential and cytotoxicity, they affect the infectious agents (Roch, 1999).

The immune parameters in shrimp are influenced by environmental factors such as temperature, salinity (Wang and Chen, 2006) and ammonia levels (Jiang et al., 2004). According to Bachére (2000), the immune parameters of $L$. vannamei are very sensitive to many factors and can be changed for no apparent reason.

Dissolved oxygen levels are directly related to good water quality. The effect of dissolved oxygen saturation values below $100 \%$ on physiology has been described by many researchers in various crustacean species. Jiang et al. (2005) evaluated the effect of hypoxia on L. vannamei, and affirmed that in 48 hours, at a dissolved oxygen concentration of $3.5 \mathrm{mg} / \mathrm{L}$, phenoloxidase activity increased, while the total hemocyte count decreased. According to Zhang et al. (2006), the physical and chemical parameters of water, the stage of development and luminosity can change the sensitivity of shrimp to lack of oxygen. Increased mortality and reduced osmoregulatory capacity were observed in Litopenaeus stylirostris under hypoxia during the moult cycle (Mugnier and Soyez, 2005). Le Moullac et al. (1998) and Cheng et al. (2002) showed that hypoxia increases the susceptibility of shrimp to bacterial diseases.

Several authors have conducted studies on the interaction between white spot syndrome virus infection and water quality parameters. Vidal et al. (2001) determined the survival rates of $L$. vannamei infected at different temperatures, obtaining $92.5 \%$ of survival at temperatures ranging from $37^{\circ} \mathrm{C}$ to $40^{\circ} \mathrm{C}$, while Rahman et al. (2006) indicated that the most effective temperature to reduce viral infectivity is $33^{\circ} \mathrm{C}$. Jiravanichpaisal et al. (2004) evaluated the effect of temperature on crayfish Pacifastacus leniusculus and found that lower temperatures reduced viral infectivity. Also, Liu et al. (2006) observed that mortality rates increase with decreased salinity in Fenneropenaeus chinensis.

In view of the above, the present study aimed to assess mortality rates, total hemocyte count (THC) and reactive oxygen species (ROS) in Litopenaeus vannamei shrimp infected with the white spot syndrome virus (WSSV) at three oxygen saturation levels.

\section{MATERIAL AND METHODS}

Three hundred and sixty (360) shrimp $(20 \pm 2 \mathrm{~g})$ of the Litopenaeus vannamei species, from a specific pathogen free (SPF) strain of compulsorily notifiable diseases by the World Organization for Animal Health (OIE), bought from Aquatec LTDA (Canguaratema, Rio Grande do Norte) and cultivated in the Marine Laboratory of Universidade Federal de Santa Catarina (UFSC) were used in the experiment. 
These animals were transported to the Laboratory of Bioassays of Instituto Federal Catarinense Campus Araquari (IFCCA), distributed in 24 tanks $(60 \mathrm{~L}$, remaining in acclimatization for 48 hours, in filtered and UV sterilized water at a temperature of $23^{\circ} \mathrm{C}, 35 \%$ salinity, under constant aeration and without feeding.

Then, the shrimp were divided into three groups, which were subjected to $30(2.07 \mathrm{mg} / \mathrm{L}), 60$ $(4.14 \mathrm{mg} / \mathrm{L})$ and $100 \%(6.9 \mathrm{mg} / \mathrm{L})$ of dissolved oxygen saturation in water, in a completely randomized design (in quadruplicate). The number of animals housed per tank was 15 , observing a maximum of four liters of water per animal. The water used had the same acclimatization conditions.

The aeration control system was composed of two gas supply networks. One network supplied air, using a blower of $0.25 \mathrm{hp}$ to the 24 tanks through a set of hoses, each one with its own air flow control. A second network distributed nitrogen for the treatment tanks with 30 and $60 \%$ dissolved oxygen saturation. The desired saturation level was obtained by the animal consumption (Le Moullac et al., 1998; Mugnier and Soyez, 2005) allied with bubbling nitrogen gas into the water column until the desired level was reached (Jiang et al., 2005). The maintenance of target oxygen saturations was performed by controlling air flow (4x/day) and keeping an ethylene vinyl acetate (EVA) layer on water surface. The layer restricted gas exchanges with the atmosphere due to decrease in air water interface.

After acclimatization, the animals remained for another 24 hours under the three experimental dissolved oxygen saturations. Then, they were divided into two groups for the experiment: 12 tanks for the infected treatment and 12 tanks for the uninfected treatment, under the same oxygen saturation conditions. The shrimp in the infected treatment were challenged with the WSSV, receiving a dose of $50 \mu \mathrm{L}$ of experimental inoculum (needle $13 \times 4.5$ ), in the abdominal muscle between the first and second segments. The animals in the uninfected treatment received shrimp virus-free as inoculum (as described by Guertler et al., 2013).
The infective material was obtained from samples collected at shrimp farms in the northern and southern regions of the state of Santa Catarina, during the 2004/2005 outbreak and stored at $-20^{\circ} \mathrm{C}$. The samples were mechanically crushed and homogenized in buffer (330mM NaCl, $10 \mathrm{mM}$ Tris, $\mathrm{pH} 7.4)(1: 10$ $\mathrm{w} / \mathrm{v})$, being centrifuged at $2000 \times \mathrm{g}$ for 20 minutes at $4^{\circ} \mathrm{C}$. The supernatant was centrifuged at $9000 \times \mathrm{g}$ for 10 minutes at $4^{\circ} \mathrm{C}$, filtered $(0.22 \mu \mathrm{m})$ and preserved in liquid nitrogen (as described by Guertler et al., 2013).

The pre-inoculum produced was injected $(50 \mu \mathrm{l})$ in healthy SPF animals (free of WSSV, IMNV and IHHNV). At the first signs of the disease, the animals were sacrificed to obtain the experimental inoculum using the methodology described above. The presence of the WSSV in the experimental inoculum was confirmed by PCR (nested-PCR, Concepto Azul ${ }^{\circledR}$ kit).

During the experiment, every 24 hours the hemolymph was collected for the assessment of total hemocyte count (THC) and reactive oxygen species (ROS), with the elimination of the sampled animals, also, the dead animals were removed and computed to assess cumulative mortality rates, and the presence of WSSV was confirmed by PCR.

The collection of hemolymph was performed with a chilled syringe containing MAS anticoagulant $(336 \mathrm{mM} \mathrm{NaCl}, 115 \mathrm{mM}$ glucose, $27 \mathrm{mM}$ sodium citrate, $9 \mathrm{mM}$ EDTA, $\mathrm{pH}$ 7.2) at the final ratio of 1:3 (hemolymph:MAS). The collection was performed in the region between the last cephalothorax and the first abdominal segments with $1 \mathrm{~mL}$ syringe coupled to a $13 \times 4.5$ needle. One aliquot of $30 \mu \mathrm{L}$ was added in anticoagulant solution with $4 \%$ formaldehyde (formaldehyde/MAS), 1:3 ratio, for cell count, and the remainder was used in ROS evaluation.

Cell count was performed using a Neubauer chamber. The ROS production was quantified by NBT reduction assay, according to Guertler et al. (2010), using laminarin $\left(2 \mathrm{mg} \cdot \mathrm{mL}^{-1}\right)$ to elicit superoxide anions $\left(\mathrm{O}_{2}^{-}\right)$production by hemocytes.

The data were tested for homoscedasticity (Levene's test) and then ANOVA factorial was performed, with $\alpha=5 \%$. Since differences were 
found between the means, Tukey test for comparison of means was used at $5 \%$ probability.

\section{RESULTS}

No mortality and no abnormal behaviors were observed in the animals from the uninfected treatments. On the other hand, 72 hours later, in the group of infected animals, some shrimp became lethargic or moved erratically, regardless of the oxygen saturation levels. Cumulative mortality was higher in the treatments were shrimp were subjected to lower levels of dissolved oxygen saturation (Figure 1). The animals that died did not develop white spots on the exoskeleton, which is a characteristic of the White Spot Syndrome.

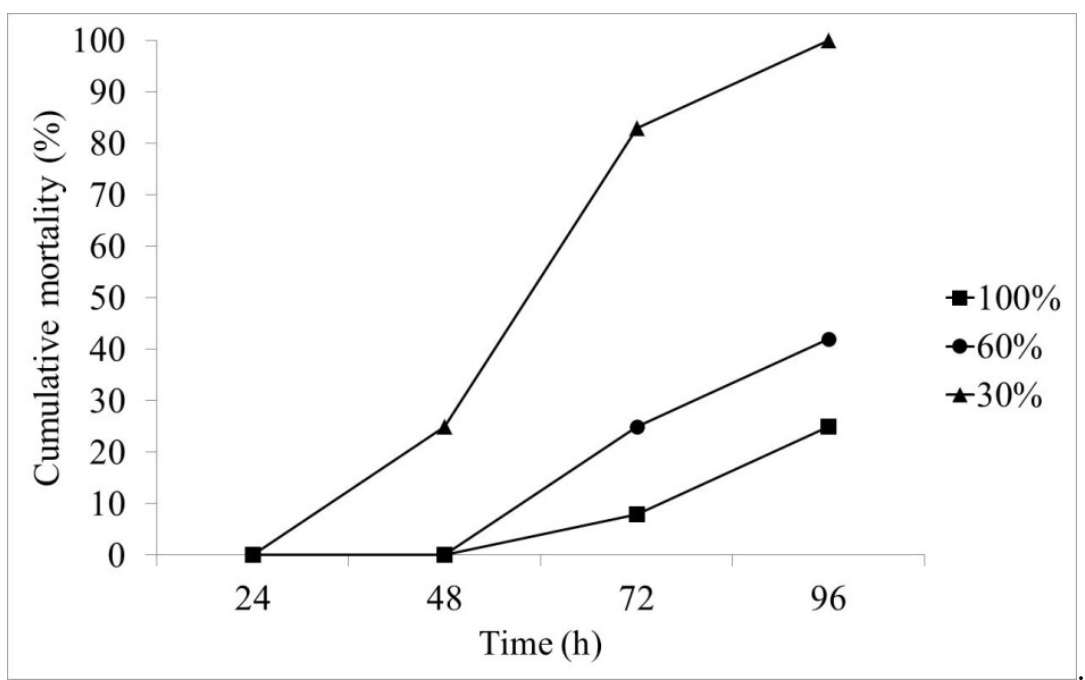

Figure 1. Percentage of cumulative mortality of $L$. vannamei during the experiment under three dissolved oxygen saturations and inoculated with the WSSV

Regarding the total hemocyte count in uninfected animals, there was no significant difference between all levels of dissolved oxygen saturation at any of the assessed periods (unreported data). The infected animals, in turn, showed a significant decrease in THC $(\mathrm{P}<0.05)$ from 48 hours on (Table 1).

Table 1. The total hemocyte count (THC) of the L. vannamei subjected to three oxygen saturation levels and challenged with the WSSV (different letters indicate significant difference by the Tukey test, $\mathrm{P}<0.05$ ).

\begin{tabular}{llllll}
\hline \multicolumn{6}{l}{ Total Hemocyte Count (number of cells $\left.\times 10^{6} . \mathrm{mL}^{-1}\right)$} \\
\hline \multirow{2}{*}{$\begin{array}{l}\text { Oxygen } \\
(\%)\end{array}$} & saturation & Time $(\mathrm{h})$ & & \\
\cline { 2 - 6 } & 0 & 24 & 48 & 72 & 96 \\
\hline 100 & $21.38 \pm 2.40 \mathrm{a}$ & $25.69 \pm 7.71 \mathrm{a}$ & $4.68 \pm 1.32 \mathrm{~b}$ & $5.48 \pm 1.95 \mathrm{~b}$ & $2.46 \pm 0.82 \mathrm{~b}$ \\
60 & $20.00 \pm 3.16 \mathrm{a}$ & $30.11 \pm 5.01 \mathrm{a}$ & $8.38 \pm 1.20 \mathrm{~b}$ & $7.97 \pm 1.33 \mathrm{~b}$ & $2.15 \pm 0.90 \mathrm{~b}$ \\
30 & $20.98 \pm 3.23 \mathrm{a}$ & $21.38 \pm 5.15 \mathrm{a}$ & $9.28 \pm 2.83 \mathrm{~b}$ & $5.32 \pm 1.41 \mathrm{~b}$ & $2.71 \pm 0.55 \mathrm{~b}$ \\
\hline
\end{tabular}

The production of reactive oxygen species showed a similar behavior in all assessed treatments, with increase in 24 hours and decrease 72 hours after inoculation. In general, the results of the uninfected treatments showed large variation, though not significant (unreported data). In the infected animals, the treatment with $100 \%$ dissolved oxygen saturation showed a significant increase $(\mathrm{P}<0.05)$ in the ROS production in $48 \mathrm{~h}$, when compared to the treatment with $30 \%$ dissolved oxygen saturation (Table 2). 
Table 2. Production expressed by absorbance of in vitro NBT reduction assay of superoxide anions in marine shrimps of the L. vannamei species subjected to three oxygen saturation levels and challenged with the WSSV (different letters indicate significant difference by the Tukey test, $\mathrm{P}<0.05$ )

\begin{tabular}{|c|c|c|c|c|c|}
\hline \multicolumn{6}{|c|}{ Reactive oxygen species production (absorbance 630nm) } \\
\hline \multirow{2}{*}{$\begin{array}{l}\text { Oxygen } \\
\text { saturation } \\
(\%)\end{array}$} & \multicolumn{5}{|c|}{ Time $(\mathrm{h})$} \\
\hline & 0 & 24 & 48 & 72 & 96 \\
\hline 100 & $0.332 \pm 0.155 \mathrm{abc}$ & $0.567 \pm 0.127 \mathrm{~cd}$ & $0.629 \pm 0.194 \mathrm{~d}$ & $0.372 \pm 0.092 \mathrm{abcd}$ & $0.349 \pm 0.078 \mathrm{abc}$ \\
\hline 60 & $0.274 \pm 0.082 \mathrm{ab}$ & $0.496 \pm 0.118 \mathrm{bcd}$ & $0.447 \pm 0.065 \mathrm{abcd}$ & $0.376 \pm 0.075 \mathrm{abcd}$ & $0.295 \pm 0.082 \mathrm{ab}$ \\
\hline 30 & $0.217 \pm 0.043 \mathrm{a}$ & $0.450 \pm 0.023 \mathrm{abcd}$ & $0.315 \pm 0.036 \mathrm{abc}$ & $0.297 \pm 0.074 \mathrm{ab}$ & $0.343 \pm 0.086 \mathrm{abcd}$ \\
\hline
\end{tabular}

\section{DISCUSSION}

The infected animals had lethargy and died, though without the occurrence of white spots, typical of the White Spot Syndrome as indicated by Mathew et al. (2007). Cumulative mortality of animals during the experiment showed significant difference regarding the dissolved oxygen saturation level in the infection treatments, indicating an influence of dissolved oxygen on shrimp survival in response to the challenge with WSSV. Similarly, Ruiz-Velazco et al. (2010) assessed the dynamic influence of the white spot syndrome virus in shrimp farms in Mexico, and reported that the increased aeration in smaller ponds reduces the impact of the white spot syndrome.

The oxygen saturation levels applied in the uninfected treatments did not show a significant influence on the THC. On the other hand, Jiang et al. (2005) noticed a decrease in the THC of shrimp of the Penaeus stylirostris species when subjected to low oxygen saturation levels (3.5 and $2 \mathrm{mg} / \mathrm{L}$ ) after 12 hours. Le Moullac et al. (1998) also performed an experiment with $P$. stylirostris under severe hypoxia $(1 \mathrm{mg} / \mathrm{L})$ for 24 hours, obtaining lower THC $(7.6 \%)$ values, and also observed that hypoxia reduced the hyaline hemocytes $(\mathrm{HH})$ and small granular hemocytes (SGH).

The decrease in hemocyte count observed in the infected treatments is common in many crustacean species infected by the white spot syndrome virus (Sarathi et al., 2007; Yeh et al., 2009; Guertler et al., 2013). Wang et al. (2002) affirm that this decrease in hemocyte count is mainly due to the decrease in small and large granular hemocytes (SGH and LGH) because they are the main WSSV targets.
The different oxygen saturation levels also did not impact the production of reactive oxygen species in the uninfected treatments. ZentenoSavín et al. (2006) assessed the ROS production in L. vannamei under hypoxia for 24 hours, and did not find a significant difference compared to normoxia. According to Le Moullac et al. (1998) and Le Moullac and Haffner (2000), the respiratory burst is not affected by hypoxia. Fridovich (2004) affirms that the percentage of oxygen consumption for reactive species is very low, around $0.1 \%$. However, 48 hours after the infection, the animals with $100 \%$ concentrations of dissolved oxygen in water showed a greater ROS production compared to the treatment with $30 \%$ saturation. Sarathi et al. (2007) also observed an increase in the respiratory burst, in 48 hours, in shrimp infected and maintained in normoxia. Li et al. (2006) and Parrilla-Taylor and Zenteno-Savín (2011) affirm that hypoxia increases the antioxidant defense of the animals. Parrilla-Taylor et al. (2013) also found that infection with WSSV stimulates the antioxidant defense. Thus, it can be suggested that the increase in antioxidant defenses caused by viral infection and hypoxia led to the low values observed in the treatment with $30 \%$ saturation. It is possible that the influence of hypoxia on the mortality of the animals is related to the defense response and not directly to the lack of oxygen.

\section{CONCLUSION}

The different oxygen saturation levels did not influence the immune parameters evaluated in uninfected $L$. vannamei shrimp. The highest mortality rates observed in infections by the white spot syndrome virus occurred under hypoxia condition, which can be related to the low ROS production observed in animals subjected to this condition. 


\section{REFERENCES}

BACHÈRE, E. Shrimp immunity and disease control. Aquaculture, v.191, p.3-11, 2000.

BARRACCO, M.A.; PERAZZOLO, L.M.; ROSA, R.D. Imunologia del camaron. In: MORALES, Q.V.; CUÉLLAR-ANJEL, J. (Eds). Guia técnica: patologia e imunologia de camarones penaeideos. Panamá: New Concept Publications, 2008. p.172-224.

BOGDAN, C.; RÖLLINGHOFF, M.; DIFENBACH, A. Reactive oxygen and reactive nitrogen intermediates in innate and specific immunity. Curr. Opin. Immunol, v.12, p.64-76, 2000.

CAMPA-CORDOVA, A.I.; HERNANDEZSAAVEDRA, N.Y.; DE PHILIPPIS, R.; ASCENIO F. Generation of superoxide anion and SOD activity in haemocytes and muscle of American white shrimp (Litopenaeus vannamei) as a response to $\beta$-glucanand sulfate polysaccharide. Fish Shellfish Immunol., v.12, p.353-366, 2002.

CHENG, W.; LIU, C.H.; HSU, J.P.; CHEN, J.C. Effect of hypoxia on the immune response of giant prawn Macrobachium rosembergii and its suceptibility to pathogen enterococcus. Fish Shellfish Immunol., v.13, p.351-356, 2002.

FRIDOVICH, I. Mitochondria: are they the seat of senescence? Aging Cell, v.3, p.13-16, 2004.

GUERTLER, C.; SCHLEDER, D.D.; BARRACCO, M.A.; PERAZZOLO, L.M. Comparative study of the intracellular superoxide anion production in different penaeid species throught the NBTreduction assay. Aquacult. Res., v.41, p.10821088, 2010.

GUERTLER, C.; RIEG, T; MEJÍA-RUÍZ, C.H. et al. Hemograma e sobrevivência de camarões marinhos após silenciamento do WSSV por RNA de interferência. Pesqui. Agropecu. Bras., v.48, p.983-990, 2013.

JIANG, G.; YU, R.; ZHOU, M. Modulatory effects of ammonia-N on the immune system of Penaeus japonicus to virulence of white spot syndrome virus. Aquaculture, v.241, p.61-75, 2004.
JIANG, L.; PAN, L.; BO, F. Effect of dissolved oxygen on immune parameters of white shrimp Litopenaeus vannamei. Fish Shellfish Immunol., v.18, p. 185-188, 2005.

JIRAVANICHPAISAL, P.; SÖDERHÄLL, K.; SÖDERHÄLL, I. Effect of water temperature on the immune response and infectivity pattern of white spot syndrome vírus (WSSV) in freshwater crayfish. Fish Shellfish Immunol., v.17, p.265275, 2004.

LE MOULLAC, G.; HAFFNER, P. Environmental factors affecting immune responses in Crustacea. Aquaculture, v.191, p.121-131, 2000.

LE MOULlAC, G.; SOYEZ, C.; SAULNIER, D.; ANSQUER, D. et al. Effect of hypoxic stress on the immune response in the resistence to vibriosis of the shrimp Penaeus stylirostris. Fish Shellfish Immunol., v.8, p.621-629. 1998.

LI, Y.; LI, J.; WANG, Q. The effects of dissolved oxygen concentration and stocking density on growth and non-specific immunity factors in Chinese shrimp, Fenneropenaeus chinensis. Aquaculture, v.256, p. 608-616, 2006.

LIU, B.; YU, Z.; SONG, X.; GUAN, Y. et al. The effect of acute salinity change on white spot syndrome outbreaks in Feneropenaeus chinensis. Aquaculture, v.253, p.163-170, 2006.

MATHEW, S.; KUMAR, K.A.; ANANDAN, R.; NAIR, P.G.V. et al. Changes in tissue defence system in white spot syndrome virus (WSSV) infected Penaeus monodon. Comp. Biochem. Physiol. C, v.145, p.351-320, 2007.

MUGNIER, C.; SOYEZ, C. Response of the blue shrimp Litopenaeus stylirostris to temperature decrease and hypoxia in relation to molt stage. Aquaculture, v.244, p.315-322, 2005.

PARRILLA-TAYLOR, D.; ZENTENO-SAVÍN, T. Antioxidant enzyme activities in Pacific white shrimp (Litopenaeus vannamei) in response to environmental hypoxia and reoxygenation. Aquaculture, v.318, p.379-383, 2011.

PARRILLA-TAYLOR, D.; ZENTENO-SAVÍN, T.; MAGALLON F.J. Antioxidant enzyme activity in pacific whiteleg shrimp (Litopenaeus vannamei) in response to infection with white spot syndrome virus. Aquaculture, v.380-388, p.41-46, 2013. 
RAHMAN, M.M.; BONILLA, C.M.E.; CORTEEL, M.; LIMA, J.J.D. et al. Effect of high water temperature $\left(33^{\circ} \mathrm{C}\right)$ on the clinical and virological outcome of experimental infections with white spot syndrome virus (WSSV) in specific pathogen-free (SPF) Litopenaeus vannamei. Aquaculture, v.261, p.842-849, 2006.

ROCH, P. Defense mechanisms and disease prevention in farmed marine invertebrate. Aquaculture, v.172, p.125-145, 1999.

RUIZ-VELAZCO, J.M.J.; HERNÁNDEZ-LLAMAS, A.; GOMEZ-MUÑOZ, V.M.; MAGALLON F.J. Dynamics of intensive production of shrimp Litopenaeus vannamei affected by white spot disease. Aquaculture, v.300, p.113-119, 2010.

SARATHI, M.; ISHAQ-AHMED, V.P.; VENKATESAN, C.; BALASUBRAMANIAN, G. et al. Comparative study on immune response of Fenneropenaeus indicus to Vibrio alginolyticus and white spot syndrome virus. Aquaculture, v.271, p.8-20, 2007.

VIDAL, O.M.; GRANJA, C.B.; ARANGUREN, F.; BROCK, J.A. et al. A profound effect of hyperthermia on survival of Litopenaeus vannamei juveniles infected with white spot syndrome virus. J. World Aquacult. Soc., v.32, p.364-372, 2001.
WANG, F.I.; CHEN, J.C. Effect of salinity on immune response of tiger shrimp Penaeus monodon and its sucetibility to Photobacterium damselae subsp. Damselae. Fish Shellfish Immunol., v.20, p.671-681, 2006.

WANG, Y.T.; LIU, W.; SEAH, J.N.; LAM, C.S. et al. White spot syndrome virus (WSSV) infect specific hemocytes of the shrimp Penaeus merguiensis. Dis. Aquat. Org., v.52, p.249-259, 2002.

YEH, S.; CHEN, Y.; HSIEH, S.; CHENG, W. et al. Immune response of white shrimp, Litopenaeus vannamei, after a concurrent infection with white spot syndrome virus and infectious hypodermal and hematopoietic necrosis virus. Fish Shellfish Immunol., v.26, p.582-588, 2009.

ZENTENO-SAVÍN, T.; SALDIERNA， R.; SANDOVAL, M.A. Superoxide radical production in response to environmental hypoxia in cultured shrimp. Comp. Biochem..Physiol. C, v.142, p.301-308, 2006.

ZHANG, P.; ZHANG, X.; LI, J; HUANG, G. The effects of body weight, temperature, salinity, $\mathrm{pH}$, light intensity and feeding condition on lethal DO levels of whiteleg shrimp, Litopenaeus vannamei (Boone 1931). Aquaculture, v.256, p.579-587, 2006. 